\title{
Analyzing the Ability of Mathematics Students as Prospective Mathematics Teachers on Multiple Mathematical Representation
}

\author{
Sudi Prayitno* \\ Departement of Mathematics Education \\ University of Mataram \\ Mataram, Indonesia \\ s.prayitno@unram.ac.id \\ Nyoman Sridana \\ Departement of Mathematics Education \\ University of Mataram \\ Mataram, Indonesia \\ sridana60@gmail.com
}

\author{
Ulfa Lu'luilmaknunn \\ Departement of Mathematics Education \\ University of Mataram \\ Mataram, Indonesia \\ ulfa_1@unram.ac.id \\ Sri Subarinah \\ Departement of Mathematics Education \\ University of Mataram \\ Mataram, Indonesia \\ s.subarinah@gmail.com
}

\begin{abstract}
This study aims to describe the ability of mathematics students as prospective mathematics teachers on multiple mathematical representations. Multiple mathematical representation is the ability to present mathematical ideas in various forms namely visual, verbal, and symbolic. The population of this study were students of the mathematics education department at a university located in Mataram, Lombok. Simple random sampling technique was used and 169 students from various class years were selected as the sample. The research instrument was in the form of a multiple mathematical representation ability test which consist of four questions in the form of an essay. Because of the Covid-19 pandemic, the data were collected through an online platform (daring) which then were analyzed by using descriptive quantitative method. Generally, the data analysis indicated that the ability of multiple mathematical representations of students was $72.73 \%$ (moderate). Specifically, it was obtained that (1) the ability of visual representation was $84.22 \%$ (high), (2) the ability of verbal representation was $71.73 \%$ (moderate), and (3) the ability of symbolic representation was $63.95 \%$ (low). It is believed that the low percentage of symbolic representation was influenced by the ability of verbal representation and problem-solving abilities.
\end{abstract}

Keywords-mathematical representation, multiple, visual, verbal, symbolic

\section{INTRODUCTION}

It was cited in the curriculum of the National Education System of the Republic of Indonesia year 2013 and National Council of Teacher of Mathematics (NCTM) [1] that there are five process skills students must possess through learning mathematics namely problem solving, reasoning, communication, connection, and representation. These five process skills are needed in developing high order mathematical thinking which indicates that these five mathematical process skills need to be studied thoroughly and deeply, as well as to be linked to the experience of the students directly. Problems on mathematical communication [2], solving problems [3], reasoning, and concept understanding have [4] been studied. In order to obtain a comprehensive overview of the five process skills, this research focuses on the problem of mathematical representations and the connections between representations known as multiple mathematical representations.

Representation is a configuration (form or arrangement) that describe, represent, or symbolizes something in a way [5]. For example, a word describes a real-life object or a number represents a position on a number line. In this case, the relation between representations can be viewed as a two-way relation. The representation process involves translating problems or ideas into new forms that include converting diagrams or physical models into symbols or words. In addition, the representation process can also be used in the translation or analysis of verbal problems to make the meaning clear [6]. Representation is the essence of learning mathematics [1]. Based on these opinions, it can be concluded that mathematical representation is the depiction, translation, disclosure, re-designation, symbolization, or modeling of an idea, concept, principle, or mathematical relations. The multiple mathematical representation model can be broadly grouped into three models, namely: (1) a visual representation model, (2) a verbal representation model, and (3) a symbolic representation model.

The ability to state and to present mathematical ideas are important things that must be done by people who are studying mathematics, including students [7]. In the process of learning mathematics, it is necessary to construct a link between the material being studied with mathematical ideas in various types of presentation models. Representation is needed in mathematics learning since it plays a role in giving students fluency in building a concept, thinking mathematically, and strengthening conceptual understanding [8]. This ability is very important for students and is closely related to communication and problem-solving skills. According to NCTM [1] "representation also help students communicate their thinking". To be able to communicate something, someone needs to make representations in the form of 
pictures, graphs, diagrams, or other forms of representation. With representation, problems that at first seem complicated and complex look simpler, so that the problems presented can be solved smoothly.

In their research, Prayitno, Kurniati, and Saputra [3] showed that the solving ability of students of mathematics education study program is classified as low. Another research conducted by Prayitno, Arjudin, and Hapipi [4] found that a high misconception of geometry among students of mathematics education courses. Furthermore, Hatagaol [9] found that the problem of representation at the primary and secondary school levels has not been handled properly so that the mathematical representation ability of students is low. Hudiono [10] found that the weakness of student representation such as presentation in the form of tables, pictures, and models is due to the delivery of representations to students only as a complement in delivering material. In addition, Minarni, Napitupulu, and Husein [11] and Fitrianna et al. [12] found that the ability of high school students to understand and represent mathematics is still low.

These situations in which the representation ability of students at the high school level still low occurs might be because the teacher is also not used to presenting mathematical ideas in various representations. Students must be accustomed to use visual representations and must be carried out with adequate practice [13]. Students of mathematics education as prospective mathematics teachers need to have multiple knowledge on mathematical representations needed to solve math problems and complete mathematics learning strategies. The enrichment of mathematical representation knowledge for prospective mathematics teachers is an absolute requirement to become professional teachers in the future and be ready to present quality mathematics learning in the $21 \mathrm{st}$ century. Therefore, it is necessary to examine the representation abilities of prospective mathematics teachers in terms of various representation models or known as the ability of multiple mathematical representations.

The idea of representation which plays an important role in learning mathematics makes this topic important to be studied. Relevant studies include the multirepresentational discourse [10], on multiple mathematical representations through an open-ended approach [14], on the ability of representation in contextual learning [9], on the ability of representation in realistic mathematics learning [15], and about increasing the ability of representation through a contextual approach [16]. This research is one of the interesting comparative studies to support the development of knowledge about multiple mathematical representations, especially multiple mathematical representations of the candidates of mathematics teacher or prospective mathematics teacher. Therefore, this study aims to describe the ability of multiple mathematical representations of mathematics students as prospective mathematics teachers.

\section{MethodS}

This research is descriptive quantitative in nature in which quantitative data were obtained through a test to measure the ability of students to represent multiple mathematical representations. The study was conducted on a population of students in the Department of Mathematics Education at a university in Mataram, Indonesia. The sampling technique used was simple random sampling, the sample consisted of 169 mathematics students in the III, V, VII, and IX semesters.

The data in this research are the ability of multiple mathematical representations. Those data were obtained through a written test which consisted of 4 essay tests. Multiple mathematical representations that had been collected contain three models, namely (1) a visual representation model, (2) a verbal representation model, and (3) a symbolic representation model. The Data were collected through an online platform during the Covid-19 pandemic. The test was carried out individually using online learning facilities (for several courses) at http://daring.unram.ac.id and WhatsApp application. The Guidelines for scoring multiple mathematical representations were based on a modification from Huda and Surya [17]. The score of the student's mathematical representation ability was then calculated based on the maximum ideal score. The percentage of students' mathematical representation ability was categorized using the category guidelines for the level of mathematical representation ability based on Purwanto [18]. After categorizing students' answers, descriptive analysis was carried out, namely describing the ability of multiple mathematical representations achieved by students. Apart from that, a model of interaction between representation models had also been sought.

\section{RESULT AND DISCUSSION}

In this research, an instrument had been developed in order to measure the ability of multiple mathematical representations which was broken down into the ability of visual, verbal, and symbolic mathematical representations. The instrument was in the form of an incomplete diagnostic test in which the students were asked to complete it according to the form of representation to be measured. Students were asked to work on 4 questions in various types of representation. The maximum score for multiple representation abilities for each item is 3 . Therefore, for this research, the criteria for the category of representation ability in Purwanto [18] need to be converted as presented in Table I.

TABLE I CONVERSION CATEGORY GUIDELINES OF MULTIPLE MATHEMATICAL REPRESENTATION ABILITY

\begin{tabular}{|c|c|c|}
\hline \multicolumn{2}{|c|}{ Representation Ability } & \multirow{2}{*}{ Category } \\
\hline In \% & In Skor & \\
\hline $90 \leq \mathrm{KR} \leq 100$ & $2,7 \leq \mathrm{KR} \leq 3,0$ & Very High \\
\hline $80 \leq \mathrm{KR}<90$ & $2,4 \leq \mathrm{KR}<2,7$ & High \\
\hline $70 \leq \mathrm{KR}<80$ & $2,1 \leq \mathrm{KR}<2,4$ & Average \\
\hline $60 \leq \mathrm{KR}<70$ & $1,8 \leq \mathrm{KR}<2,1$ & Low \\
\hline $0 \leq \mathrm{KR}<60$ & $0,0 \leq \mathrm{KR}<1,8$ & Very Low \\
\hline
\end{tabular}

The results of data analysis on students' multiple mathematical representation abilities can be seen in Table II.

Table II The Results of Data Analysis of Students' Multiple Mathematical Representation Ability

\begin{tabular}{|c|c|c|c|c|}
\hline \multirow[t]{2}{*}{ No } & \multirow[t]{2}{*}{$\begin{array}{c}\text { Measured } \\
\text { Representation }\end{array}$} & \multicolumn{2}{|c|}{$\begin{array}{c}\text { Representation } \\
\text { Ability }\end{array}$} & \multirow[t]{2}{*}{ Category } \\
\hline & & Score & $\%$ & \\
\hline
\end{tabular}




\begin{tabular}{|c|l|c|c|c|}
\hline 1 & $\begin{array}{l}\text { Verbal } \\
\text { Representation }\end{array}$ & 2,04 & 68,05 & Low \\
\cline { 2 - 5 } & $\begin{array}{l}\text { Symbolic } \\
\text { Representation }\end{array}$ & 1,59 & 52,86 & Very Low \\
\hline 2 & $\begin{array}{l}\text { Visual } \\
\text { Representation }\end{array}$ & 2,86 & 95,26 & Very High \\
\cline { 2 - 5 } & $\begin{array}{l}\text { Symbolic } \\
\text { Representation }\end{array}$ & 2,65 & 88,36 & High \\
\hline 3 & $\begin{array}{l}\text { Visual } \\
\text { Representation }\end{array}$ & 2,34 & 78,10 & Average \\
\cline { 2 - 5 } & $\begin{array}{l}\text { Verbal } \\
\text { Representation }\end{array}$ & 1,62 & 53,85 & Very Low \\
\cline { 2 - 5 } & $\begin{array}{l}\text { Symbolic } \\
\text { Representation }\end{array}$ & 1,23 & 40,83 & Very Low \\
\hline \multirow{2}{*}{4} & $\begin{array}{l}\text { Visual } \\
\text { Representation }\end{array}$ & 2,38 & 79,29 & Average \\
\cline { 2 - 5 } & $\begin{array}{l}\text { Verbal } \\
\text { Representation }\end{array}$ & 2,79 & 93,29 & Very High \\
\cline { 2 - 5 } & $\begin{array}{l}\text { Symbolic } \\
\text { Representation }\end{array}$ & 2,21 & 73,77 & Average \\
\hline \multicolumn{2}{|l|}{ Means } & 2,17 & 72,37 & Average \\
\hline
\end{tabular}

Based on Table II, it can be calculated that the ability of multiple mathematical representations of mathematics students is presented in the form of a bar chart in Figure 1.

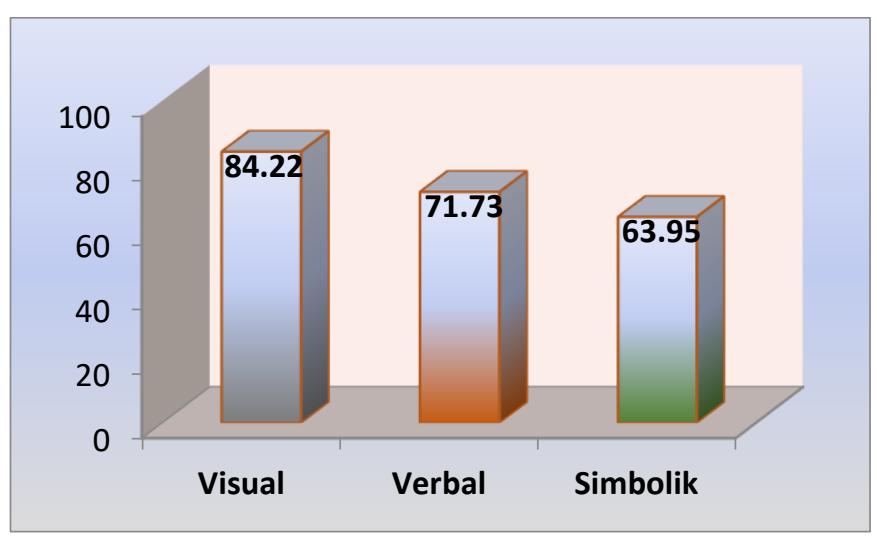

Fig. 1. the ability of visual, verbal, and symbolic representation of prospective mathematics teacher.

Based on Table 2 and Figure 1, the multiple representation abilities of prospective mathematics teachers are as follows. In general, the students' multiple mathematical representation ability reached $72.73 \%$ or in the average category. Students' visual representation ability reaches $84.22 \%$ or is in the high category. Students' verbal representation ability reached $71.73 \%$ or in the average category. The ability of student symbolic representation reaches $63.95 \%$ or in the low category.

As shown in Figure 1 and Table 2, the multiple representation abilities of students reached $72.73 \%$ or in the medium category. Figure 1 also indicates the differences in the ability to represent visual, verbal, and symbolic.

Students' visual representation ability reaches $84.22 \%$ and is in the high category. This indicates that students do not experience problems when converting various information into visuals or images. Figure 2 below is the student's worksheet in transforming information in the form of verbal representations into visual representations.

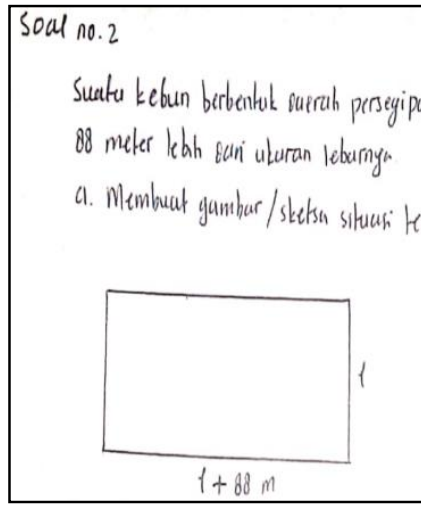

Fig. 2. Changing Information in the Form of Verbal Representations into Visual Representations

Figure 3 is the student's works in changing visual representations to other forms. Students were asked to make questions based on pictures and solve them at once. The questions and answers made by the students were predominantly symbolic representations, with little verbal. Here, students were able to use the information provided in the image to be converted into problems and the solution in other forms of representation.

Furthermore, it was discussed that the ability of students to represent multiple mathematical representations in the form of verbal representations means the ability of verbal mathematical representation is the ability to present mathematical information in the form of words. Based on the data analysis presented in Table 2 and Figure 1, the ability of students' verbal mathematical representation reached $71.73 \%$ and is in the sufficient category. In order to measure the ability of verbal representation, students had been exposed to information in the form of visual or symbolic representations, then students were asked to make questions in the form of words.

In Figure 4, based on symbolic and visual information, students made questions that are applied in nature, namely looking for the minimum value of a target function. The questions made by students contain verbal and symbolic information that has not been applied to applied questions in everyday life which tend to be in the form of verbal representations. The ability of verbal representation for prospective mathematics teacher who is in average condition is influenced by mathematical communication skills. This is in line with the results of Prayitno's research [19] which states that students (especially boys) have difficulty expressing mathematical information in the form of words. If asked what is a rectangle? Students cannot mention the exact definition or characteristics of a rectangle but can present it in the form of images or visuals appropriately. Umaroh and Pujiastuti's research [20] also found that the verbal representation ability of the students they studied was in an average category, students were less confident in expressing the answer in the form of words, but students could present their answers visually well. This might be because visual representations are easier for students to solve math problems. The benefit of visual representation is that it helps students distinguish important relationships between variables, quantities, and relational terms in mathematical problems [21]. Visualization has an 
important role in describing mathematical concepts, exploring mathematical relationships, and solving mathematical problems [22].

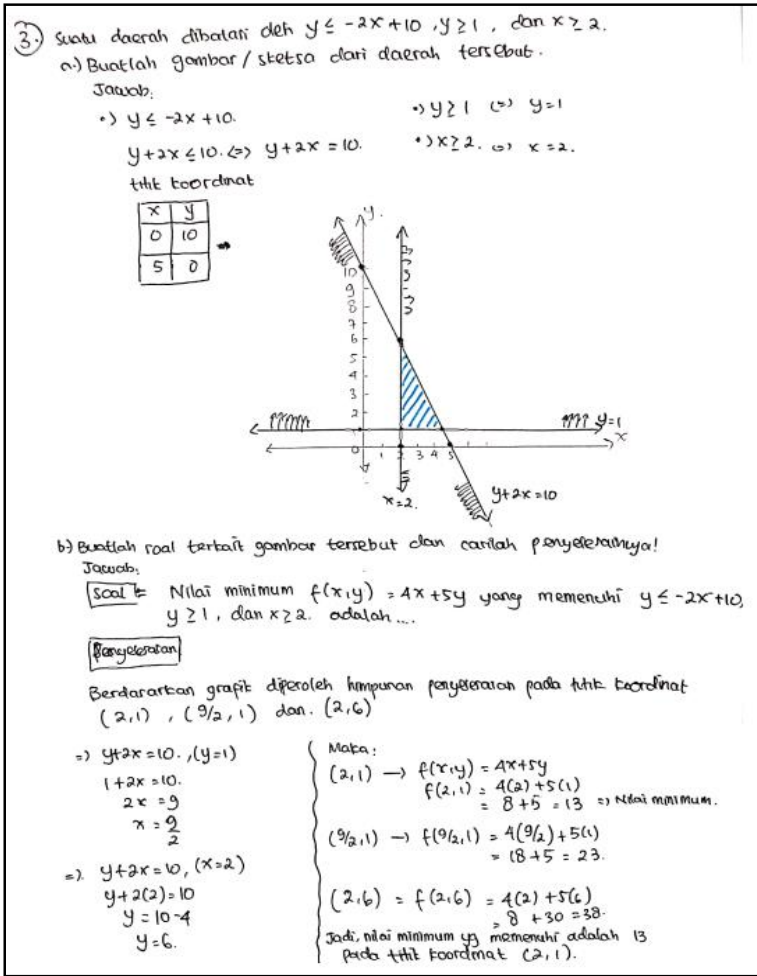

Fig. 4. Use of Information in the Form of Symbolic Representations to Reveal the Ability of Visual, Verbal, and Symbolic Representations

The next discussion is about the ability of multiple mathematical representations of symbolic forms. The symbolic form of mathematical representation is a form of presenting mathematical ideas in the form of symbols, which can be in the form of variables, parameters, terms, numbers, or notations. Symbol is a short form of meaning that can be expressed in words, for example, symbol $\Delta$ means triangle, symbol $\leq$ means less than or equal to, symbol $\mathrm{x} 2$ means the variable $\mathrm{x}$ (or something) is squared or squared, and so on. The language of mathematics is synonymous with the language of symbols, a language that is less meaningful to those who do not learn it.

The ability of students to represent multiple mathematical representations in symbolic form reaches $63.95 \%$ or is included in the low category. The ability of symbolic representation is measured by solving the problems made by the students themselves. The low ability of symbolic representation is influenced by the ability to solve problems. The problem-solving ability of students of mathematics education study program that was studied previously indicated low ability, especially in geometry problems, where students had difficulty compiling symbolic mathematical models of geometric problems that were presented verbally [3]. The results of this study are in line with Dewi et al. [23] that the representation ability of students is low due to the ability to compose a mathematical model (symbolic) and present it in the form of words (verbal). Luo's research [24] also found something similar to this study, namely that a significant percentage of prospective mathematics teachers could not understand the problem of multiplying fractions by being given a symbolic representation. Likewise, Duru's research [25] found that candidates of mathematics teachers have higher scores in graphic or visual representations than symbolic representations.

\section{CONCLUSION}

Based on the findings and discussions, it can be concluded that in general, the ability of multiple mathematical representations of mathematics students reaches $72.73 \%$ or in the average category. The visual representation ability reaches $84.22 \%$ or is in the high category. The ability of verbal representation of mathematics reached $71.73 \%$ or in the average category. The ability of symbolic representation reached $63.95 \%$ or in the low category. The low ability of student symbolic representation is due to the quality of the questions made by the students and the ability to compose mathematical models in the problem-solving process. The relations obtained between the three representational abilities is that the ability of visual representation affects the ability of verbal representation, and both of them affect the ability of symbolic representation.

The results of this research can be used as evaluation material for the improvement of lectures in the Mathematics Education, undergraduate program and can be used as a reference for further research. Suggestions that can be given are based on the results of this study which are educators should be able to learn mathematics in a meaningful way, not just symbols without meaning. The application of the problem-posing learning model needs to be applied to improve verbal representation skills which will affect increasing symbolic representation.

\section{ACKNOWLEDGMENT}

We would like to thank DIPA BLU of the University of Mataram for funding this research in 2020 with the agreement contract number: 2626 / UN18.L1 / PP / 2020.

\section{REFERENCES}

[1] NCTM, Curriculum and Evaluation Standards for School Mathematics. Reston VA: NCTM Inc, 2000.

[2] S. Prayitno, "Mathematical communication profile of field independent students in solving mathematics problem based on gender differences," in The 2015 International Conference on mathematics, its applications, and mathematics education, 2015, pp. 184-195.

[3] S. Prayitno, N. Kurniati, and I. Saputra, "Kemampuan Pemecahan Masalah Mahasiswa Calon Guru Matematika," in Prosiding Seminar Nasional Saintek 2018 tanggal 27 Oktober 2018 di Lombok Plaza Hotel, 2018, pp. 539-547.

[4] S. Prayitno, A. Arjudin, and H. Hapipi, "Analyzing Geometry Misconception of Prospective Teachers Using Three-Tier Diagnostic Test," vol. 465, no. Access 2019, pp. 119-122, 2020 , doi: 
[5] G. Goldin, Perspective on Representation in Mathematical Learning and Problem Solving”. In L. D. English (Ed.), no. 2009. New Jersey: Lawrence Erlbaum Associates, 2002.

[6] NCTM, Curriculum and Evaluation Standards for School Mathematics. Reston VA: NCTM Inc, 1989.

[7] N. Selvia, A. A. R. Awaludin, and F. R. Andrari, "The design of student mathematical representation instrument on problem solving reviewed from introvert-extrovert personality," $J$. Phys. Conf. Ser., vol. 1318, no. 1, 2019, doi: 10.1088/1742-6596/1318/1/012062.

[8] Jones, "The fifth process standard: An argument to include representation in standards 2000," 200AD. [Online]. Available: http://www.math.umd.edu/ dac/650/jonespaper.ht ml. [Accessed: 20-Feb-2020].

[9] K. Hutagaol, "Pembelajaran Kontekstual Untuk Meningkatkan Kemampuan Representasi Matematis Siswa Sekolah Menengah Pertama," Infin. J., vol. 2, no. 1, p. 85, 2013, doi: 10.22460/infinity.v2i1.27.

[10] B. Hudiono, "Peran Pembelajaran Diskursus Multi Representasi terhadap Pengembangan Kemampuan Matematika dan Daya Representasi pada Siswa SLTP," J. Cakrawala Kependidikan, vol. 8, no. 2, pp. 101-110, 2010.

[11] A. Minarni, E. E. Napitupulu, and R. Husein, "Mathematical understanding and representation ability of public junior high school in North Sumatra," J. Math. Educ., vol. 7, no. 1, pp. 43-56, 2016, doi: 10.22342/jme.7.1.2816.43-56.

[12] A. Y. Fitrianna, S. Dinia, M. Mayasari, and A. Y. Nurhafifah, "Mathematical Representation Ability of Senior High School Students: An Evaluation from Students' Mathematical Disposition," JRAMathEdu (Journal Res. Adv. Math. Educ., vol. 3, no. 1, p. 46, 2018, doi: 10.23917/jramathedu.v3i1.5872.

[13] E. Debrenti, "Visual Representation in Mathematics Teaching: An Experiment With Students," Acta Didact. Napocensia, vol. 8, no. 1, pp. 19-26, 2015.

[14] S. Fadillah, "Meningkatkan Kemampuan Representasi Multipel Matematik, Pemecahan Masalah Matematik dan Self Esteem siswa SMP melalui Pembelajaran dengan Pendekatan Open Ended," J. Pendidik. Mat., vol. 2, no. 2, 2011.

[15] S. Sulastri, M. Marwan, and M. Duskri, "Kemampuan Representasi Matematis Siswa SMP Melalui Pendekatan Pendidikan Matematika Realistik," Beta J. Tadris Mat., vol. 10, no. 1, p. 51, 2017, doi: 10.20414/betajtm.v10i1.101.

[16] R. Nursanti, 'Improving Students' Mathematical Representation Ability Through Student Worksheets: a Contextual Approach on the Topic of Relation and Function for Eighth Grade Students of Junior High School 3 Batu Ampar," J. Pendidik. Mat. dan IPA, vol. 10, no. 2, p. 122,
2019, doi: 10.26418/jpmipa.v10i2.29665.

[17] A. Huda and E. Surya, "Process Analysis of Student Answers from Students' Mathematical Representation Ability Tests in the Subject Opportunities for Class IX-1 of SMP Negeri 17 Medan," 2018. [Online]. Available: https://www.researchgate.net/publication/3294507 01

Process_Analysis_of_Student_Answers_from_Stu dents' Mathematical_Representation_Ability_Tes ts_in_the_Subject_Opportunities. [Accessed: 20Feb-2020].

[18] Purwanto, Evaluasi Hasil Belajar. Yogyakarta: Pustaka Pelajar, 2011.

[19] S. Prayitno, "Profil Kemampuan Komunikasi Matematis Siswa SMP dalam Menyelesaikan Soal Matematika Ditinjau dari Perbedaan Gaya Kognitif dan Gender," Program Pascasarjana Universitas Negeri Surabaya, Surabaya, 2017.

[20] U. Umaroh and H. Pujiastuti, "Analisis Kemampuan Representasi Matematis Siswa dalam Mengerjakan Soal PISA Ditinjau dari Perbedaan Gender," J. Pendidik. Mat. Raflesia, vol. 05, no. 02, pp. 40-53, 2020.

[21] A. K. Jitendra and J. Woodward, The Role of Visual Representations in Mathematical Word Problems, 1st ed., vol. 5. Elsevier Inc., 2019.

[22] M. A. Rau, V. Aleven, and N. Rummel, "Successful learning with multiple graphical representations and self-explanation prompts," $J$. Educ. Psychol., vol. 107, no. 1, pp. 30-46, 2015, doi: 10.1037/a0037211.

[23] I. Dewi, S. Saragih, and D. Khairani, "Analisis Peningkatan Kemampuan Representasi Matematis Siswa SMA Ditinjau dari Perbedaan Gender," $J$. Didakt. Mat., vol. 4, no. 2, pp. 115-124, 2017, doi: $10.24815 / j d m . v 4 i 2.8863$.

[24] F. Luo, "Evaluating the effectiveness and insights of pre-service elementary teachers' abilities to construct word problems for fraction multiplication," J. Math. Educ., vol. 2, no. 1, pp. 83-98, 2009.

[25] A. Duru, "Pre-service teachers' perception about the concept of limit," Educ. Sci. Theory Pract., vol. 11, no. 3, pp. 1710-1715, 2011. 